\title{
A MAGYAR POLGÁRI ELITEK ÉRTÉKRENDSZERE ÉS REGIONÁLIS VÁLTOZATAI
}

\author{
(Values and Regional Varieties of the Hungarian Bourgeois Elites)
}

\section{GYÁNI GÁBOR}

Kulcsszavak:

elit arisztokrácia polgárság kollektív emlékezet

A szerzö jelen tanulmányában a Magyarországot irányító elit társadalmi összetételének kialakulasát taglalja az Osztrák-Magyar Monarchia korában, és hangsúlyozza, hogy a hagyományos elit csoportok (arisztokrácia és a korábbi földtulajdonos középnemesség) politikai elitként éltek tovább. Ez a tendencia ugyanakkor a két világháború közötti idöszakban megvaltozott, akkor kerültek ugyanis hatalomra a növekvö számú új tagok, különösen a "hosszú 1930-as években”. A polgári közép- és felsöközép osztály gyors felemelkedése és gazdasági-társadalmi megalapozottsága a 19. század közepén történt meg. A tanulmányt gyakorlatilag egy rövid esettanulmány zárja, amely egy 1940-es évekbeli, középosztálybeli pécsi hölgy irásos gyüjteményén alapul, és amelynek célja a helyi középosztályok határozott belsỏ integrációjának demonstrálása a felekezeti, származási és foglalkozásbeli különbségek ellenére.

Az eredetileg Gaetano Mosca, valamint Vilfredo Pareto által a 19-20. század fordulóján kidolgozott elit-elmélet sugalmazása szerint nincs társadalom kormányzás (kormányzó elit) nélkül. Az általa birtokolt (monopolizált) hatalom pedig mindig kevesek kezébe van letéve, ilyen értelemben oligarchikus (Mosca 1884; 1896; Pareto 1902; 1916). Persze, a liberális alkotmányos, majd a demokratikus társadalmak nem oligarchikus szerveződésüek, noha nekik is vannak elitjeik (Runciman 1963).

Ezt az ellentmondást Joseph A. Schumpeter (1950) igyekezett elviekben áthidalni azáltal, hogy kijelentette: az elit vagyis a politikai vezetöréteg ezekben a társadalmakban a piaci verseny körülményei közt megszerezhetö, és a fékek, valamint az ellensúlyok közepette megtartható elitbeli pozíció várományosa és letéteményese. E szerint ,a demokrácia nem jelenti, nem jelentheti azt, hogy ténylegesen a nép uralkodna, bárhogy értjük is a »nép« és az »uralom «kifejezéseket. A demokrácia annyit jelent csupán, a népnek megvan rá a lehetősége, hogy elfogadja vagy visszautasítsa a felette uralkodó embereket.” Hiszen, folytatja Schumpeter: „a demokratikus módszer a politikai döntések megszerzésének azon intézményes rendje, melyben egyesek az emberek szavazatárt folyó versenyszerü küzdelemben megszerzik döntésre jogosító hatalmukat." (Schumpeter 1950, 284-285) A despotizmus liberális demokrácián belüli ellenszere ilyenformán az egymással szüntelenül versengö kormányzó elitek vetélkedése a szavazók kegyének elnyeréséért; ennek során a hatalmi pozíciót birtokba vevő elitet idővel a vele versengő másik elit váltja le. A demokratikus hatalmi apparátus demokratizmusát garantálja továbbá, hogy az elit diffúz, mert megfelelően széles társadalmi spektrumból kerül ki a tagsága; következés- 
Gyáni Gábor : A magyar polgári elitek értékrendszere és regionális változatai.

Tér és Társadalom 24. évf. 2010/2. 5-16. p.

képpen számtalan társadalmi csoport tudja képviseltetni magát a hatalmi gépezetben önnön elitjein keresztül.

A fékek és egyensúlyok ebben az esetben oly fontos tényezője az elitek cirkulációjaként és decentralizációjaként szokott megfogalmazódni a szociológiai és társadalomtörténeti gondolkodásban. Az elitcsere ténylegesen adott lehetösége, amely a pártrendszeren nyugvó demokráciákban a pártok váltógazdaságaként teremtődik meg, s nem utolsósorban az elit rekrutációjának a társadalmi demokratizmusa (az elit nyitottsága avagy zártsága), végül pedig az elit tagok életformabeli (mentalitásbeli) közelsége vagy távolsága a tömegekhez (exkluzivitása avagy köznapisága) mind-mind fontos fokméróje a politikai rendszer demokratizmusának.

Nem elég azonban a demokrácia megvalósulását egyedül csak a politika piaci mủködési módjához kötni, úgy ahogyan Schumpeter teszi. Tény ugyanis, hogy többnyire szük és behatárolt (vagyis antidemokratikus) a demokráciák kormányzó elitjeinek társadalmi merítési bázisa. Ez közvetlenül a társadalmi egyenlötlenségek adott rendszeréből fakad, ezen belül vagy emellett az egyes társadalmi csoportoknak az iskolához (iskoláztatáshoz) való differenciált hozzájutásának a következménye. Pierre Bourdieu (1978) olyan rekonverziós stratégiákat állapított meg, amelyek kiegészítik a gazdasági vagyon átadásával biztosított reprodukciós eljárásokat. „E stratégiák az iskolai címet fokozatosan a profit elsajátításának legalábbis formális feltételévé... alakították." (Bourdieu 1978, 374) Ezzel a módszerrel srófolják egyre följebb az elitbeli pozícióhoz megkövetelt iskolai végzettség fokát, miközben a tudásbeli kompetencia kívánatos jellegét is elóírják. Kulcsszerepe van az elitek rendszerint antidemokratikus kiválogatódási folyamatában a kulturális (szimbolikus) tőke megszerzésének és megörzésének. Franciaországban pl. az 1880-as években megindult egyetem- és iskolareformok burkoltan arra irányultak, hogy kibövuiljön az elit hagyományos merítési bázisa; a notabilitások, vagyis a polgári elit növekvő köreit vonták be ily módon a kormányzó elitbe. Ez a "taláros burzsoázia" (bourgeoisie de robe), amely jogvégzett állami fötisztviselöket és választott politikai tisztségviselöket (parlamenti képviselöket) tömörít a soraiban (Charle 2008).

Ehhez hasonló folyamat ment végbe Magyarországon is, amikor az 1870:42. tc., majd pedig az 1871:18. tc. nyomán bevezették a virilis rendszert a helyhatósági képviseleti rendszerbe. Ezeknek a rendelkezéseknek az értelmében az egyenes állami adó és a mủveltség központi szerepet kapott a választással szemben a helyi (a megyei, városi, községi) elit pozíciók birtokba vételénél (Sarlós 1976). Ezáltal tágult, egyszersmind pluralizálódott (decentralizálódott) az addig csupán születési alapon (nemesi státushoz kötött, tehát úri jogon) elnyert elit pozíciók társadalmi alapja, ami felgyorsította a helyi elitek cirkulációját (Halmos 2006).

Nem ilyen ,demokratikus” ugyanakkor a központi kormányzó elit társadalmi képlete. A dualizmus évtizedeiben az alsóházi, a népképviseleti országgyülési képviselök 10-15\%-a rendszerint a sziuletési arisztokrácia soraiból került ki, akik aránya idővel még nőtt is: 1869 és 1878 között a hercegek, grófok és bárók együttes aránya $10 \%$ körül mozgott az országgyülési képviselök között, a század végén 14-15\%, az 1910-es években pedig 16-17\% között alakult az arányuk. A mindenkori kormány- 
párt parlamenti mandátumait ennél is gyakrabban birtokolták arisztokraták: az arisztokrácia parlamenti mandátummal rendelkező tagjainak legkevesebb a fele, gyakran kétharmada, nemritkán a háromnegyede tartozott ilyenformán a kormányzó elitbe (Toth 2000, 1073-1074).

A kormányzó eliten belüli arisztokrata jelenlétet tovább növelte a fơrendiház, ahol kizárólag a születési fönemesség képviseltette magát (bár nem minden arisztokrata kapott erre felhatalmazást). A förendiház 1885-ös reformja (7. tc.) ugyanis a vagyonosabb, a háromezer forint felett adózó fỏnemesek számára tette csupán lehetővé a testületi tagságot. A megszorítás eredményeként a születési arisztokrácia (férfi tagjainak) alig több mint a negyede (!) került be ezek után a förendiházba (Vörös Károly 1987). $\mathrm{Az}$ arisztokrácia tekintélyes része, mint ahogyan az ebből is látható, némileg elszegényedett. Ráadásul egy merőben új elit „értékelési rend” kezdett ez idő tájt kialakulni hazánkban, amely immár vagyonhoz (gazdasági teljesítményhez) is kötötte a gyakran csupán megörökölt elit pozíció megszerzését.

A kormányzó elit országgyűlési képviselőkböl adódó hányadának a nagyobb részét valójában a széles értelemben vett középosztály adta: ebben pedig elsősorban a hagyományos társadalmi csoportok, a volt bene possessionati tagjai képviseltették magukat. Az 1880-as években az országgyưlési képviselök megközelítően fele része, az első világháború előestéjén is a kétötöde (a századforduló éveiben azonban olykor csupán a harmada) került ki a birtokos középosztály soraiból. A dzsentri kifejezéssel jelölt társaság képezte a kormányzó elit egyik magját, míg az a középosztály alkotta a másikat, amely tisztviselökbỏl, ügyvédekböl és másféle polgári elemekböl (kereskedőkből, gyárosokból, bankárokból, egyéb vállalkozókból, szabadfoglalkozású értelmiségiekből) rekrutálódott. A tisztviselók és az ügyvédek jelenléte itt a fontos: az országgyülési képviselök rendszerint egytizede tisztviselökből került ki, az ügyvédek viszont a mandátummal bírók átlagosan egyhatodát, némely esetben közel a negyedét tették ki (Toth 2000, 1088).

A politikai demokrácia szempontjából egyszerre volt előre és egyszerre volt hátra lépés a Horthy-kor. Elöre lépés történt, mert jelentősen megemelkedett a választók számaránya: a korábbi, átlagosan 5,5-6,5\%-os szintről 1920-ra nyomban 40\%-ra ugrott a választásra jogosultak aránya, jóllehet ezt követően már folyton csökkent, és végül $30 \%$ körül állandósult. Hátra lépés történt ellenben a szabadságjogok tekintetében, miután a tisztán liberális dualista állami és társadalmi rendet konzervatív, tekintélyuralmi politikai rezsim váltotta fel, amely az antiliberális (korporatív) fejlemények és nem a politikai demokrácia irányába volt nyitott (Ormos 1998; Piiski én.).

A két háború között (kivált a két háború idején) megnőtt az állam társadalmon belüli szerepe, következésképpen fokozódott a politikai (a kormányzó) elitnek az élet politikán kívuili dolgaira gyakorolt befolyása is. A bethleni korszakban (1921-1931) a köztisztviselöi posztokat huzamosan elfoglalók, továbbá az értelmiség, a volt katonatisztek és a nagybirtokosok képviseltették magukat nagy számban a politikai eliten belüil. A „hosszú” harmincas években (tehát 1944-ig bezáróan) a szerényebb anyagi helyzetú középosztályi (és kispolgári) személyek elött nyílt meg a politikusi (állami főtisztviselöi) karrier szédítő lehetősége; a korábban katonatisztként, köz- 
Gyáni Gábor : A magyar polgári elitek értékrendszere és regionális változatai.

Tér és Társadalom 24. évf. 2010/2. 5-16. p.

hivatalnokként, értelmiségiként ténykedő, az elit utánpótlási forrásaként azelőtt érdemben semmilyen szerepet sem játszó elemek érkeztek - látványos pártkarriert befutva - ez időben a csúcsra (Gyáni-Kövér 2004).

A bethleni korszak nemzetgyülésében (1926-ig) és az országgyülés két kamarájában (1927-től), valamint egyes kormányhivatalokban egyformán számottevő volt a nagybirtokosok és az arisztokrácia számszerủ jelenléte, ami a hagyományos, a nem polgári elit többé-kevésbé folytonos fennmaradását bizonyítja; magyarán Trianon után elmaradt Magyarországon az elitcsere. A többnyire jómódú, nemegyszer kifejezetten gazdag parlamenti képviselök (kormányhivatalnokok) személyükben a multipozicionális elitet képviselték.

A harmincas évek politikai vezető garnitúrája teljesen új, ráadásul alacsonyabb társadalmi rétegekböl rekrutálódó személyekből került ki, akik kizárólag az államból (és az államnak) élö hivatásrendi csoportot kezdtek alkotni, akik abban voltak elsősorban érdekeltek, hogy rendelkezési hatalmuk latba vetésével társadalmi elit pozíciót szerezzenek maguknak. Ez az új politikai osztály a jobbratolódás, a politikai totalitarianizmus ügyét mozdította elő, mert így remélhette csupán osztályhelyzete, a kormányzói mellett a többi elit státus tényleges birtokba vételét. Ebbéli törekvését az eredetileg német óhajra is hozott zsidótörvények bizonyítják. A zsidóság, vagyis a polgári elit és középosztályok, valamint az alsó zsidó rétegek foglalkozási, vagyoni és politikai diszkriminációját lépésenként valóra váltó kormánypolitika a tulajdon, az alkalmazotti jövedelmek és a munkaerö-piaci pozíciók állami újraelosztását célozta; melynek meg is lett az eredménye. A zsidó tőkés osztály árjásítása arra irányult tehát, hogy az újonnan felemelkedett politikai elit mihamarabb rátehesse kezét a mobil tỏkére (Ungváry 2002a; 2002b).

Miután röviden áttekintettük az elitek általános történeti pályáját a 19. század utolsó harmadától a második világháború végéig, a következőkben vessük tehát pillantásunkat a polgári elitre.

A ,polgár”, a „tőkés”, valamint a ,vállalkozó” terminusok sok mindent jelenthetnek (Gyáni 1997). Amikor az osztályfogalom elvi alapjául szolgáló érdek fogalmát az identitás (és az imázs) kategóriájával cseréljük fel a társadalmi makrocsoportok megragadásakor, elsőrendü kérdéssé válik, hogy ki minek tekintette és miként alkotta meg magát társadalmi értelemben. Az utóbbi az életstílus, a fogyasztás és az életstratégiák, nem utolsósorban a kultúra fogalmi keretében objektiválódik ${ }^{1}$. Ily módon felértékelödik a szubjektivitás és a mindennapi életgyakorlat súlya és szerepe a társadalmi struktúra fogalmi megkonstruálása során.

A tỏkés fejlődés kezdetei a refomkorba, az előfutárok koráig nyúlnak nálunk vissza, ezt a Grïnderzeit időszaka követi (Gyáni 2004). Elvétve maradt hosszú távon is talpon az alapítók nagy nemzedéke, csekély a személyi kontinuitás mind időben visszafele, mind pedig elöre. Így a két hábonú közötti gazdasági és polgári elit, az „örökösök” sem feltétlenül egyenes ági leszármazottai a századforduló polgári elitjének és felső 
középosztályának. Mindez arra utal, hogy az egyéni életpályák stagnáló, sỏt hanyatló szakaszainak a vizsgálata is elengedhetetlen az emelkedés regisztrálása mellett. Felmerül a kérdés: volt-e érdemi befolyása idehaza a Buddenbrook-effektusnak, hogy ti. három nemzedékig tart csupán a családi vállalatok felívelése, amelyre többnyire hanyatlás következik (Barker-Lévy-Leboyer 1982; Lengyel 1989)?

Hazánkban nem adatott meg három, különösen nem ennél több egymást követö tőkés nemzedék számára a zavartalan karrierút lehetösége. Az elcsatolt területeken éló vállalkozók életében már Trianon meghozta a kényszerủ véget. Az 1930-as évek végétól pedig a zsidóság politikai diszkriminációja volt az, ami Magyarországon letérítette a tőkés társadalom belső evolúcióját a megszokott útról. Végül a második világháború utáni rendszerváltozás, sőt rendszerváltások akadályozták meg a polgári elit (és középosztály) létezésének folytonosságát.

A 20. század során az időben elörehaladva egyre szembeszökőbb a diszkontinuitás a vállalkozó és menedzser elit társadalmi és személyi összetételét tekintve. Néhány kivétel azonban itt is akad, amilyen például a pécsi Zsolnay család vagy a Chorin dinasztia (Strasserné Chorin-Bán 1999; Jávor 2000; Gyáni 2003). Mind a két esetben sikerült az alapító nemzedék utódainak megismételni apáik kimagasló gazdasági teljesítményét. Igaz, a harmadik nemzedékkel az említett esetekben is megszakadt az időbeli folytonosság.

Honnan érkeztek és kik voltak személy szerint a magyarországi kapitalizmus hajdani megteremtői, majd pedig a fenntartói? Általánosságban kijelenthetjük: a modern tỏkés nagypolgárság, valamint a polgári középosztály szük belső magja nem a születésénél fogva volt a magyar nemesi társadalomhoz tartozó társadalmi (felekezeti, etnikai) csoportok leszármazottja.

Ennek ellenére sem állítható azonban, hogy polgárságunk kizárólag azokból a zsidó eredetủ családokból rekrutálódott volna, akik a 18. században és a 19. század első felében vándoroltak be és telepedtek meg Magyarországon. Hiszen akadtak köztïk már hosszabb ideje itt élő németajkú és újabban bevándorolt, jóllehet nem zsidó származású személyek is. Feltűnően sokan érkeztek pl. Svájcból (Ganz Ábrahám, Haggenmacher Henrik), és kivált a német területekről vagy a Skandináviából történő bevándorlás volt a jellemzö (Halmos 2004a; 2004b; Klement 2004).

A bevándorlás és a polgári elit etnikai eredetének a kérdése nem egyszerủ probléma. A gyors kulturális asszimiláció során idővel csökkent, sőt olykor szinte el is enyészett a származási megkülönböztetés mint folytonosan nyilvántartott társadalmi attribútum. A középkorban betelepült erdélyi és felvidéki szászok (a cipszerek), vagy a 18. században ide telepített svábok idegennek tekinthetők-e vajon hosszabb idö elteltével, és egy kalap alá vehetők-e mondjuk a 19. századi németajkú bevándorlókkal? Némileg így áll a helyzet a 18. században bevándorolt morvaországi és a 19. század folyamán érkező galíciai zsidókkal is, miközben szintén alapvető különbségek forrása a városba költözés időpontja mindenekelött a zsidók adaptációja során (vö. Csíki 1999).

Nem tartható fenn tovább azon széles körben hangoztatott nézet, mely szerint a zsidóság úgymond kisajátította magának az üzleti foglalkozásokat, valamint a szabadpályás értelmiségi hivatásokat, hogy ennek fejében átengedje a politikai pozíciókat 
Gyáni Gábor : A magyar polgári elitek értékrendszere és regionális változatai.

Tér és Társadalom 24. évf. 2010/2. 5-16. p.

és az állami-közületi alkalmazotti állásokat a nemeseknek, pontosabban leszármazottaiknak, a keresztényeknek. Ezt a mondandót foglalja magában az ,asszimilációs társadalmi szerzödés” koncepciója (Karády 1997, 84). Jóllehet valóban kevés a nemesi származású üzletember és úgyszintén csekély a zsidó származású (és nem kikeresztelkedett) politikusok vagy közhivatalnokok száma a dualizmusban, később pedig még inkább; ez azonban önmagában nem bizonyíték a társadalmi struktúra megkettőződésére, amely a modern kori magyarországi társadalmi fejlődésnek a dogmatikus felfogás szerinti fő megkülönböztetö jegye 2 .

Ezt a közismert és máig népszerü tézist elvetve a magunk részéröl azt hangsúlyozzuk, hogy a honi kapitalizmus a zsidó, a német és a többi bevándorolt (mondjuk így: a nem magyar eredetü), továbbá a nemesi származású elemek osztatlan közös müve volt. Tényszerúen kimutatható ugyanis, hogy az úgynevezett dzsentri, illetve arisztokrata összetételủ politikai elit és államhivatalnoki kar (a dualizmus korában legalábbis) kielégíto módon adminisztrálta a piacgazdaságot, politikailag megfelelően irányította és kézben tartotta tehát az indusztrializáció és az urbanizáció feszuiltségekkel teli folyamatát. A feudalizáció-tézis viszont egyúttal arra világít rá, hogy az uizleti élet képviselői, valamint a modern szakértelmiség egyes tagjai erös késztetést éreztek magukban a hagyományok átvételére és tovább éltetésére, mely attitüd jótékonyan közrehatott társadalmi integrációjuk előmozdításában. Nem csak a gyakori zsidó nemesítés, valamint a nagypolgárságban elö-előforduló kikeresztelkedés (McCagg 1985; Konrád 2009), hanem a zsidó nagytökések, de bizony még a zsidó felsőközéposztálybeliek, sőt olykor az alsó zsidó népelemek mohó földszerzési vágya (Kövér 2002; 2004) is ennek igazán beszédes bizonyítéka. Az utóbbi törekvés a Buddenbrook-effektus sajátos mechanizmusaként is felfogható talán. A pénzüket földvásárlásba fektetö leszármazottak (mert ők éltek leginkább ezzel a lehetőséggel) gyakran éppen így vonultak ki az üzleti életből járadékossá alakulva át ezáltal (Kövér 2002).

Az asszimiláció, tehát a nyelvi-kulturális, majd strukturális adaptáció a befogadók oldalán elpolgáriasodást vont maga után. A valamikori tényleges jelentőségéhez képest nem vagy alig észlelt, a történészek által nem kellően regisztrált folyamat az életformák terében ment végbe, amelynek ezek szerint nem a politikai viselkedés és a politikai értékek jelentik elsô számú indikátorát ${ }^{3}$.

Különösen ez utóbbi szempontjából van, lehet nagy súlya a helyi, tehát az országos szint alatti és a budapestin kívüli elitek történeti kutatásának. Kevés feltáró munka folyt e téren, közuilük Szakál Gyula (2002) és Takács Tibor (2008) monográfiája emelkedik ki tudományos jelentőségét tekintve (Györ és Nyíregyháza a két említett könyv szorosabban vett tárgya). Az említett két munkából kitünik, hogy a helyi elitek az országosnál (és a budapestinél) összehasonlíthatatlanabbul integráltabbak voltak belülről. A jövedelmi forrását, származását és foglalkozását tekintve szintén heterogén szóban forgó elitcsoportok közelebb állnak tehát vidéken egymáshoz kifejezetten a szociabilitásukat tekintve, mint országosan és a fôvárosban.

Vizsgáljuk meg a kérdést ezúttal egy sajátos megközelítés segítségével. Mint ahogyan korábban már említettem, a társadalmi szerkezet rekonstruálása során erőteljesen építeni kell a státus szubjektív összetevőjének ismeretére, az identitás konstitutív 
szerepére az egyén pontos társadalmi helyének a kijelölése során. Ennek során figyelembe lehet, sőt kell venni a kollektív emlékezet struktúrát konstituáló erejét is; erre veszek irányt a következőkben, amikor egy ritka és sajátos forrást kapcsolok be az elemzésbe.

Különösen nagy súllyal nehezedett az utolsó fél, háromnegyed évszázad során a (tỏkés) polgárság múltjára a tudatos felejtés, majd a nyílt dezavuálás terhe. Kezére játszott mindennek, hogy a „hosszú” 19. századot követően uralkodó diskurzussá és meghatározó társadalmi (politikai) gyakorlattá vált a hangos és durva antiliberalizmus, a vele összefonódó harcos polgárellenesség. A Horthy-kor már indulása pillanatában nyilvánvalóvá tette a pálfordulás e nyomatékos tényét, amely a növekvő állami antiszemitizmus (numerus clausus) tényében, évtizedekkel később pedig a zsidótörvényekben, majd a genocídiumban (holokauszt) kulminált. Bizonyos értelemben ezt a fajta beállítottságot folytatta a kommunista totalitarianizmus határozott polgárellenessége is. Ezek nyomán a „polgár” és a ,polgári” kifejezések mindinkább szitokszóvá alakultak; baloldalon a társadalom többségét nyomorba döntő „here” réteg szinonimájaként, jobboldalon a zsidó élösködővel azonosított „,kártevő” fogalmaként emlegették a szóban forgó kifejezéseket. A heveny polgárellenesség beszédes tettekben is gyakran megnyilatkozott: kezdetben, mint zsidópolitika, utóbb, mint osztálypolitika végezte el a polgárság fizikai, morális és szellemi megsemmisítésének a feladatát.

Így vált (válhatott) a polgár (a vállalkozó, a menedzser és a szabadpályás értelmiség) lassanként felejtés tárgyává, hogy végül csak mint rossz, kedvezőbb esetben nosztalgikus emlék kerüljön szóba a többnyire politikailag intonált diskurzusokban. E folyamat a kollektív emlékezet generációs kereteinek a felbomlásával párhuzamosan ment végbe. Maurice Halbwachs (1992) szerint a kollektív emlékezetet életben tartó társadalmi keretek a családhoz (is) kötődnek; ebben az esetben a rokonsági kötelékek által egybefüzött emberekre, az általuk közvetlenül érintett eseményekre és személyekre vonatkozik az emlékezetben tartott múlt fogalma. A kollektív emlékezet e fajtája különösen megfelel annak a célnak, hogy szilárd identitásra tehessen szert általa az individuum, és hogy a közösségi folytonossági tudat is épségben fennmaradhasson. Amikor azonban az emlékezet jelzett társadalmi keretei egyszer csak bomlásnak indulnak, nyomban vagy hamarosan a kollektív emlékezet folytonossága is megszakad, és amnézia lesz úrrá a múlt ily módon megsemmisülö világán (Halbwachs-Coser (1992).

A családi (rokoni) társadalmi közösségi keretek emlékezetet teremtő, egyszersmind széles körủ tudást és társadalmi öntudatot nemző szerepét igazolja az a kivételes forrás is, melyet nagy haszonnal forgathatunk jelen témánk szempontjából. Gosztonyi Gyuláné, szül. Pilch Erzsébet pécsi polgárasszony 1940-ből való emlékezésérỏl van szó, melyet unokái okolására vetett szerzője papírra (Egy pécsi... 2003). Az emlékezö nemesi családból származik, akinek ügyvéd és kúriai bíró volt 
Gyáni Gábor : A magyar polgári elitek értékrendszere és regionális változatai.

Tér és Társadalom 24. évf. 2010/2. 5-16. p.

az apja, a férje pedig ítélötáblai bíróként ténykedett. Emlékezései megörökítésében testvére, a pécsi építészmérnök, a helyi müemlékek aktív kutatója és helyreállítója inspirálta. Úgy beszéli el Gosztonyiné a pécsi polgárság akkori társadalmi jelenét és közeli múltját, hogy a pontos életrajzi és élettörténeti adalékokon túl olykor még személyes karakterrajzokra is futja az erejéböl. Részben a szüleitöl, olykor pedig másoktól hallott, de gyakran éppen a saját tapasztalataiból ismert korabeli pécsi polgárság elevenedik meg emlékezésében a maga extenzív teljességében. A hallomásból ismert és ezúttal tovább is adott emlékanyagra jellemzö példaként idézem az alábbi részletet. „Paschiczky Józsefre csak homályosan emlékszem, inkább szüleim beszéltek róla, ő orvosunk volt fiatal korában. Az én nagyapám lakott az ő házukban a Megye utcában, ahol ma a püspöki uradalom fötisztje lakik. Leánya volt a csodaszép Angéla, Nagy huszár ezredes felesége, kinek lányát elvette Balogh Aladár huszár ezredes, Balogh Károly táblabíró fia." (Egy pécsi... 2003, 35)

Emlékezőnk személyes tudása kap ugyanakkor hangot, midön a legnagyobb pécsi fafeldolgozó vállalkozó tulajdonosával kapcsolatban leírja: „Kisleány koromban élénken emlékszem vissza, amikor anyámmal, aki a nőegylet elnöke volt, szegények részére adományokat gyüjtöttünk és betértünk az akkori Indóház utcán szemben a református templommal egy csinos parkírozott udvaron lévö úri házba és annak nagy teraszán iildögélt egy idös elegáns házaspár. Ezek voltak Ráth Mátyás és neje, barátságos emberek és igen bökezủek, akik nagyon segítették a szegényeket. Szlavóniából jöttek Pécsre és igen vagyonos emberek voltak. Két lányuk volt, Wollenszky állomásfönök felesége, a másik Mária, Hoffmann Károly mủasztalos gyáros és bútor nagykereskedő felesége." (Egy pécsi... 2003, 41) Ezt követően hosszan sorolja tovább Gosztonyiné a család további leszármazottait, akik közül számosan idöközben már értelmiségivé lettek (orvosok, építészmérnökök). S így megy ez hosszú oldalakon keresztuil.

A kivételesen becses forrásból tanulságként levonhatjuk, hogy amikor közvetlenül adottak még a kollektív emlékezet örzése szempontjából fontos családi „társadalmi keretek" (Halbwachs-Coser 1992), egy Pécshez fogható közepes nagyságú város teljes polgári és középosztályi világa elfér egyetlen személy tudatában és emlékezetében. Gosztonyiné ugyanis mindent tud vagy tudni vél az ôt és családját szorosan környezö középosztályi (polgári) világról ${ }^{4}$. Fontos megjegyezni, hogy Gosztonyiné életszerü, jóllehet imaginárius jellegű beszámolója a pécsi polgári és középosztályi társadalomról egyáltalán nem támasztja alá ténybeli bizonyítékokkal a társadalmi struktúra állítólagos kettősségének már említett tudományos elképzelését. Söt, ennek éppen ellentmondó véleményt fogalmaz meg a szerző időnként, mint amikor például kijelenti: „Ha figyelmesen olvastátok [mármint az unokák] e családokat, láthatjátok, hogy itt Pécsett mindig is összetartottak az iparosok, kereskedők a tisztviselö famíliákkal, legtöbbször egy fiú vitte tovább a mesterséget, a többi már katona, vagy hivatalnok lett.” Később úgy általánosít, hogy megállapítja: „Jellemző vonásuk volt a pécsi »bürgereknek«, hogy gögösek, rátartiak voltak a vagyonukra, ami sok ajtót kinyitott előttük. Általában jó megjelenésüek voltak, sokat utaztak, szép háztartást vezettek, remek konyhájuk volt és sokat adtak külsejükre. A fiúk urizáltak, 
sportoltak, lovagoltak, lumpoltak, csak a házasság vitte őket vissza a rendes életmódhoz, amit azután meg is tartottak." (Egy pécsi... 2003, 43)

Milyen célra használhatja a történész ezt a múltban ránk maradt memóriát? Tekintheti-e vajon úgy, mint amely társadalomtörténeti tényeket tár a szeme elé; vagy pusztán a mentális valóság tükreként lehet és kell azt hasznosítani? Mind a két feltevést kész vagyok a magamévá tenni, bár az utóbbi elfogadása felé hajlok inkább.

Továbbra is Pécs városánál maradva, hadd utaljak e helyen Jávor Katának a Zsolnay családról szóló, már idézett kismonográfiájára (Jávor 2000), annak egynémely eredményére és tanulságára. A szóban forgó vállalkozó család életének egyikmásik sorsdöntő eseményét, nevezetesen a testvérek, mint örökösök közötti viszályt tisztázandó, a mủ szerzője többnyire a családi emlékezet (tehát egy kései leszármazott) közléseire hagyatkozik. Jávor döntése teljességgel érthetö, hiszen nincs a történeti igazságot kézzelfoghatóan tanúsító irott dokumentum a kezében a kérdést illetôen. Nem árt azonban némi óvatosság e téren. A család leszármazottainak az emlékezete, mint valamely utólag konstruált családtörténeti legendárium olykor még napjainkban is hallható „hangja” sokkal inkább a képzelt, semmint a ténylegesen megtörtént valóságról ad számot a Zsolnayak esetében is. Nem puszta fantáziálás ez persze, ugyanakkor közvetlenül „csak” arról az imaginárius valóságról tudósít, amire az emlékezőknek a valamikori identitásuk megteremtéséhez és fenntartásához volt égetően nagy szükségük ${ }^{5}$. Ebbéli minőségében pedig aligha tekinthető feltétlenül megbízható ténybeli forrásnak az emlékezeti tanúságtétel egyes életesemények megtörténtének és lefolyásuk mikéntjének tekintetében. Ráadásul a családi legendák ,adatai” szinte soha sem ellenőrizhetők más források adataival, akár csak mások emlékezeti tanúságtétele révén sem. Ha tehát a historikus kizárólag rájuk támaszkodik, akkor módfelett kiszolgáltatja magát a partikuláris látószög kénye-kedvének.

Abban az esetben nyer a kérdés átlagost meghaladó jelentőséget, amikor végleg eltủnnek a kollektív emlékezet családi (és másféle) társadalmi keretei, mellyel veszendőbe is megy a múlt szüntelen emlékezetben tartása. Ez a folyamat be is következett a 20. század folyamán a vállalkozó közép- és nagypolgár famíliák életében, akik közös végzetszerủ sorsa lett 1945-öt (és még inkább 1950-et) követöen a gazdasági hanyatlás, a szétszóratás, valamint az új identitások kényszerủ keresése.

Amikor néhány éve (2004) napvilágot látott a Sokszínü kapitalizmus. Pályaképek a magyar tókés fejlödés aranykorából címü, Sebök Marcell által szerkesztett történetírói munka, melyben 14, zömmel nagytökés család pályafutásáról szólnak a különféle esettanulmányok, a kiadó találkozót szervezett a szerzők és a könyv történelmi polgár család höseinek ma is élő leszármazottai számára. Az összejövetel számos tanulsággal szolgált mostani témánkra nézve is.

A többnyire már az újabb nemzedékekhez tartozó leszármazottak, valamint a személyi folytonosságot még képviselni hivatott idősebb családtagok beszámolói szerint a privát családi emlékezet napjainkra már erôsen megkopott. Ami nem csoda, ismerve az érintett családok társadalmi deklasszálódását, ami horizontális társadalmi integrációjuk (egyebek közt kapcsolati tőkéjük) erodálását eredményezte. Nem tartották ugyanis többé számon egymást, sőt nemegyszer szem elöl is vesztették egymást, 
Gyáni Gábor : A magyar polgári elitek értékrendszere és regionális változatai.

Tér és Társadalom 24. évf. 2010/2. 5-16. p.

ami szükségszerủen fakadt a szétszóratásukból. Ez oda vezetett, hogy a hazai történeti polgárságból mára már végképp kiveszett az a valamikori kétségtelen lelki és szellemi kohézió, amely a csoporthoz tartozók identitásának döntő tapasztalati alapját képezhette (vö. Gyáni 2007).

Az összejövetel tudatosította a valamikori nagy-és középpolgár családok mai leszármazottaiban, hogy nem adottak többé számukra a történelmi azonosságtudat megteremtésének és fenntartásának azok a lehetőségei, amelyek felmenőik élettörténeteiben még kulcsszerepet játszottak a polgári mivolt átélésében és bizonyításában egyaránt. Mindez pedig nyilvánvalóvá teszi, hogy visszavonhatatlanul lezárult valamikor a 20. század derekán a magyar polgárság történelmi pályafutása; olyan múlt ez ma már, melynek a történetírók állíthatnak immár csupán emléket textusok alkotta monumentumok formájában. A hagyomány által tovább adott tudás, az ennek megfelelö történelmi öntudat azonban, amelynek a polgárság kollektív emlékezete is az egyik fontos tárgyi feltétele volt a még nem is túl távoli múltban, ilyenformán menthetetlenül tehát a múlt ködébe veszett.

\section{Jegyzetek}

${ }^{1}$ Ez irányban tapogatózik az utóbbi évtizedek polgárságtörténete, vö. Gay (1984; 2002). Hasonló hazai törekvés a jelenség poétikai köntösben való megragadására Fried (2003).

${ }^{2}$ A dogma bírálatához vö. Gyáni (2002, 88-97). A kérdés történetírói diskurzusának újabb hullámaihoz ld. Vörös Kati (2002-2003), Klement (2006, 205-216), Balázs-Szelényi (2006, 152-160) és Bódy (2007) müveit. A probléma elsỏ empirikus történészi megközelítésére példa Hanák (1992). A kötet hét történész különféle esettanulmányait tartalmazza.

${ }^{4}$ A korabeli pécsi polgári életforma leírását és elemzését ld. Lakatos (1992).

${ }^{5}$ A társadalmi imaginárius fogalmához vö. Maza (2003, 10-11).

\section{Irodalom}

Balázs, A.-Szelényi, I. (2006) The Failure of the Central European Bourgeoisie. New Perspectives on Hungarian History. Palgrave, Macmillan, New York.

Barker, T.C.-Lévy-Leboyer, M. (1982) An Inquiry into the Buddenbrooks Effect in Europe. -Hannah, L. (ed.) From Family Firm to Professional Management: Structure and Performance of Business Enterprise. Akadémiai Kiadó, Budapest. 9-25. o.

Bódy Zs. (2007) „Polgárság” és „polgárosodás” fogalma Erdei Ferenc kettőstársadalom-koncepciójában és a társadalom történet-írásban. - Kommentár. 3. 3-15. o.

Bourdieu, P. (1978) Rekonverziós stratégiák. - Bourdieu, P. A társadalmi egyenlötlenségek újratermelódése. Tanulmányok. Gondolat, Budapest. 350-378. o.

Charle, Ch. (2008) Elite Formation in Late Nineteenth Century France: France Compared to Britain and Germany. - Historical Research - Historische Sozialforschung. 2. Special Issue: Elite Formation in the Other Europe (19th-20th Century). 250-252. o.

Csíki T. (1999) Városi zsidóság Északkelet-és Kelet-Magyarországon. Osiris, Budapest.

Egy pécsi polgárasszony emlékei a városról. Gosztonyi Gyuláné, született Pilch Erzsébet visszaemlékezései a 19. és 20. század fordulójáról. (2003) Tanulmányok Pécs történetéböl 16. Pécs Története Alapítvány, Pécs.

Fried I. (2003) Egy/a polgári család és vidéke. (Márai Sándor „családi” krónikája). - Mühely. 2. 51-63. o. 
Gay, P. (1984) The Bourgeois Experience. Victoria to Freud. Vol. I. Education of the Senses. Oxford University Press, New York.

Gay, P. (2002) Schnitzler's Century. The Making of the Middle-Class Culture 1815-1914. W. W. Norton \& Company, New York.

Gyáni G. (1997) Polgár, polgárosodás. - Mühely. 6. 59-61. o.

Gyáni G. (2002) Polgárság és középosztály a diskurzusok tükrében. - Gyáni G. Történészdiskurzusok. L'Harmattan, Budapest. 88-97. o.

Gyáni G. (2003) Chorin Ferenc (1879-1964). - Szentpéteri J. (szerk.) Szürke eminenciások a magyar történelemben. Kossuth Kiadó, Budapest. 150-153. o.

Gyáni G. (2004) Elöszó. Az újra felfedezett polgári múlt. - Sebők M. (szerk.) Sokszínü kapitalizmus. Pályaképek a magyar tôkés fejlödés aranykorából. KFKI Csoport, HVG, Budapest. 13-21. o.

Gyáni G.-Kövér Gy. (2004) Magyarország társadalomtörténete a reformkortól a második világháborúig. Osiris, Budapest. 223-236, 240-247, 381-388. o.

Gyáni, G. (2007) Middle-Class Kinship in Nineteenth-Century Hungary. - Sabean, D.W.-Teuscher, S.Mathieu, J. (eds.) Kinship in Europe. Approaches to Long-Term Development (1300-1900). Berghahn Books, New York. 284-300. o.

Halbwachs, M.-Coser, L.A. (1992) On Collective Memory. The University of Chicago Press, Chicago.

Halmos K. (2004a) Gregersen Gudbrand. Ácslegényböl építési nagyvállalkozó. - Sebök M. (szerk.) Sokszínü kapitalizmus. Pályaképek a magyar tókés fejlődés aranykorából. KFKI Csoport, HVG, Budapest. 58-71. o.

Halmos K. (2004b) Haggenmacher Henrik és Károly. Malomipar és serfőzés. - Sebök M. (szerk.) Sokszínü kapitalizmus. Pályaképek a magyar tỏkés fejlödés aranykorából. KFKI Csoport, HVG, Budapest. 72-83. o.

Halmos K. (2006) Besitzbürgertum Magyarországon. (A virilizmus). - Kövér Gy. (szerk.) Zsombékok. Középosztályok és iskoláztatás Magyarországon a 19. század elejétől a 20. század közepéig. Századvég, Budapest. 190-194. o.

Hanák P. (szerk.) (1992) Polgári lakáskultúra a századfordulón. MTA TTI, Budapest.

Jávor K. (2000) Életmód és életmód-stratégia a pécsi Zsolnay család történetében. Akadémiai Kiadó, Budapest.

Karády V. (1997) A zsidóság polgárosodásának és modernizációjának főbb tényezői a magyar társadalomiörténetben. - Karády V. Zsidóság, polgárosodás, asszimiláció. Tanulmányok. Cserépfalvi, Budapest. 78-114. o.

Klement J. (2004) Ganz Ábrahám. - Sebök M. (szerk.) Sokszínü kapitalizmus. Pályaképek a magyar tökés fejlödés aranykorából. KFKI Csoport, HVG, Budapest. 42-71. o.

Klement J. (2006) Nagypolgárság a két világhábonú közötti Magyarországon? Egy társadalmi réteg meghatározásának lehetơségeiröl. - Kövér Gy. (szerk.) Zsombékok. Középosztályok és iskoláztatás Magyarországon a 19. század elejétól a 20. század közepéig. Századvég, Budapest. 205-216. o.

Konrád M. (2009) Vallásváltás és identitás. A kitért zsidók megítélésének változásai a dualizmus korában. - Századok. 3. 593-636. o.

Kövér Gy. (2002) M. L. Herzog \& Comp. Három nemzedék öröksége. - Kövér Gy. A felhalmozás íve. Társadalom- és gazdaságtörténeti tanulmányok. Új Mandátum, Budapest. 62-73. o.

Kövér Gy. (2002) Nagy vagyonok legendáriuma. - Kövér Gy. A felhalmozás íve. Társadalom- és gazdaságtörténeti tanulmányok. Úij Mandátum, Budapest. 151-173. o.

Kövér Gy. (2004) Performációk I. „Zsidó társadalom” Tỉszaeszláron a nagy per elöestéjén. - Korall. Szeptember. 5-42. o.

Lakatos M. (1992) Élet egy régi pécsi polgárcsaládban. - Hanák P. (szerk.) Polgári lakáskultúra a szán zadfordulón. MTA TTI, Budapest. 121-140. o.

Lengyel Gy. (1989) Vállalkazók, bankárok, kereskedök. A magyar gazdasági elit a 19. században és a 20. század elsö felében. Magvetó Kiadó, Budapest.

Maza, S. (2003) The Myth of the French Bourgeoisie. An Essay on the Social Imaginary, 1750-1850. Harvard University Press, Cambridge.

McCagg, W.O. (1985) A fóbb vitapontok. Fontos-e a zsidó nemesség? - Simon R. (vál.) Zsidókérdés Kelet- és Közép-Európában. ELTE, Budapest. 385-453. o.

Mosca, G. (1884) Sulla teorica dei governi e sul governo parlamentare. Palermo.

Mosca, G. (1896) Elementi di scienza politica. Roma.

Ormos M. (1998) Magyarország a két világháború korában (1914-1945). Csokonai, Debrecen.

Pareto, V. (1902) Systémes socialistes. Giard et Brière, Paris.

Pareto, V. (1916) Trattato di sociologia generale. Brace and Company, New York.

Püski L. (én.) A Horthy-rendszer (1919-1945). Pannonica, Budapest. 257-280. o. 
Gyáni Gábor : A magyar polgári elitek értékrendszere és regionális változatai.

Tér és Társadalom 24. évf. 2010/2. 5-16. p.

Runciman, W.G. (1963) Social Science and Political Theory. Cambridge University Press, Cambridge. Sarlós B. (1976) Közigazgatás és hatalompolitika a dualizmus rendszerében. Akadémiai, Budapest. 25-111. o. Schumpeter, J.A. (1950) Capitalism, Socialism and Democracy. Harper and Row Publishers, New York.

Sebök M. (szerk.) Sokszínü kapitalizmus. Palyaképek a magyar tókés fejlódés aranykorából. KFKI Csoport, HVG, Budapest.

Strasserné Chorin D.-Bán D.A. (1999) Az Andrássy úttól a Park Avenue-ig. Osiris, Budapest.

Szakál Gy. (2002) Vállalkozó györi polgárok 1870-1940. Sikeres történeti modellváltás. L'Harmattan, Budapest.

Takács T. (2008) Döntéshozók. Városi elit és városi önkormányzat Nyirregyházán a XX. század elsö felében. L'Harmattan, Budapest.

Toth, A. (2000) Die Soziale Schichtung im Ungarischen Reichstag 1848 bis 1918. - Rumpler, H.Urbanitsch, P. (Hrsg.) Die Habsburgermonarchie 1848-1918. Band VII. Verfassung und Parlamentarismus. Verlag der Österreichischen Akademie der Wissenschaften, Wien. 1061-1105. o.

Ungváry K. (2002a) „Árjásítás” és a „modernizácio”. Adalékok Imrédy Béla miniszterelnök müködéséhez és a zsidótörvények. - Századvég. 4. 3-37. o.

Ungváry K. (2002b) „Nagy jelentőségủ szociális akció”. Adalékok a zsidó vagyon begyüjtéséhez és elosztásához Magyarországon 1944-ben. - Rainer M. J.-Standeisky É. (szerk.) Évkönyv 2002. 1956-os Intézet, Budapest. 287-321. o.

Vörös Károly (1987) A förendi ház 1885. évi reformja. (Egy kutatás tervei és első eredményei.) Á. Varga L. (szerk.) Társadalomtörténeti módszerek és forrástípusok. Nógrád Megyei Levéltár, Salgótarján. 397-405. o.

Vörös, Kati (2002-2003) A Unique Contract. Interpretations of Modern Hungarian Jewish History. Kovács, A.-Andor, E. (eds.) Jewish Studies at the Central European University III. CEU, Budapest. 229-255. o.

\section{VALUES AND REGIONAL VARIETIES OF THE HUNGARIAN BOURGEOIS ELITES}

\section{GÁBOR GYÁNI}

The elite theory elaborated in the late 19th and early 20th century (Gaetano Mosca, Vilfredo Pareto) was pioneering in acknowledging that the democratic governments led by elites are also oligarchies. Joseph Schumpeter, however, held that the people have the opportunity of accepting or refusing the men who are to rule them. Democracy is thus achieved through the free competition for the vote of the electorate.

The author outlining in recent study the evolution of the social composition of Hungary's governing elites in the age of the Austro-Hungarian Monarchy, argues that traditional elite groups (aristocracy and the former middle-sized landholding nobility) survived as a political elite. This, however, changed in the interwar period when increasing number of new recruits came to power especially in the "long 1930s". In terms of the swift emergence and socio-economic establishment of the bourgeois middle- and upper middle classes taking place following the mid-19th century several hotly disputed historical issues like the Jewish assimilation and the Buddenbrooks-effect are also discussed.

Lastly, a short case study based on a written recollection coming from the 1940 s and produced by a middle-class lady from Pécs is to demonstrate the unambiguous internal integration of the local middle classes despite their diversity by race (denomination), lineage or occupation. 